\title{
PROSES BERPIKIR REFLEKTIF SISWA KELAS X MAN NGAWI DALAM PEMECAHAN MASALAH BERDASARKAN LANGKAH KRULIK DAN RUDNICK DITINJAU DARI KEMAMPUAN AWAL MATEMATIKA
}

\author{
Ulfa Masamah $^{1}$, Imam Sujadi $^{2}$, Riyadi $^{3}$ \\ ${ }^{1,2,3}$ Prodi Magister Pendidikan Matematika, FKIP Universitas Sebelas Maret Surakarta
}

\begin{abstract}
The aim of this research was to describe reflective thinking process of $10^{\text {th }}$ grade MAN Ngawi students with different initial mathematics capability (high, normal, low) in solving problems based on Krulik and Rudnick steps. This research was a kind of qualitative research on a case study. The collecting data in this study used task-based on interview method. The analyzed of the data in this study did with reducing the data, presenting the data, and conclusing the data. The results of this research were: 1) on reading and thinking step, students with normal and low initial mathematics capability convince what they read and thought correctly by reading repeatedly. Students with high initial mathematics capability did it by reading and understanding each question sentences repeatedly; 2) on exploring and planing step, selecting and considering information, both students with high and normal initial mathematics capability did these steps by information identification and analysis of main problems and conditions; to convince that initial problem solving planning was right, they did it by organizing problem and deciding the initial steps planned; 3) on selecting a strategy step, to consider confidently the problem solving step based on information obtained, students with high initial mathematics capability did the step by exploring initial problem solving strategy and using representation result by trial-error and guessing test, concerning problem solving pattern, and recheck every step done. Students with normal initial capability did it by exploring initial problem solving strategy and using representation result by trial-error step, making proper initial plan by question stimulation. 4) on finding an answer step, to understand each steps based on selected problem solving strategy, both students with high and normal initial mathematics capability did it by (a) ascertain formula that used for the area of that shapes, triangle area if known two sides which flank an angle, and comparing trigonometry on special angle correctly (students with normal capability used question stimuly); (b) trying repeatedly using selected patterns and recheck every step and calculation done; and (c) aware of each mistakes (computation, formula, way, and writing) and fixed them (students with normal capability needed question stimuly and wrong answering strategy). Student with high initial capability combined the process by paying attention and rechecking every steps and calculation by step back process. 5) on reflecting and extending step, to considering results and problems, students with high initial mathematics capability did it by reflection to get solution and rechecking by verification process. Students with normal capability did it by rechecking and looking back the problem and result obtained. In every steps, students with high initial mathematics capability always used intuition and self-questioning to convince the step done. $10^{\text {th }}$ grade MAN Ngawi students with low initial mathematics capability did not use reflective thinking in problem solving based on Krulik and Rudnick.

Keywords: Process, reflective thinking, problem solving, and initial mathematics capability.
\end{abstract}

\section{PENDAHULUAN}

Pemecahan masalah merupakan suatu proses berpikir (Krulik dan Rudnick, 1988:

3). Lebih lanjut, Krulik dan Rudnick menjelaskan bahwa individu dihadapkan pada situasi yang tidak biasa dan dituntut menggunakan pengetahuan, keterampilan, dan pemahaman yang diperoleh sebelumnya untuk menemukan dan menganalisis solusi. 
Situasi masalah disajikan untuk mengarahkan siswa berpikir sistematis terhadap kemungkinan cara dan hasil yang diperoleh, mengorganisasikan berbagai pengetahuan dan pengalaman, serta menyimpan dan memanggil kembali berbagai pengetahuan dan keterampilan untuk mempermudah proses memecahkan masalah (NCTM, 2015). Masalah baru benar-benar telah diselesaikan apabila siswa tersebut memahami apa yang dikerjakan, yakni memahami proses pemecahan masalah dan memahami mengapa solusi yang telah diperoleh tersebut sesuai (McIntosh, 2000). Gagatsis dan Patronis (1990) menjelaskan bahwa melalui mengamati, mengajukan pertanyaan, dan memahami apa yang dimaksudkan masalah inilah seseorang memiliki kesempatan yang baik untuk berpikir reflektif, selanjutnya disebut sebagai awal dari proses berpikir reflektif matematis.

Berpikir reflektif merupakan pertimbangan yang kuat, tetap dan cermat terhadap keyakinan atau bentuk pengetahuan apapun yang cenderung dianggap benar (Dewey, 1933). Berpikir reflektif merupakan aspek penting yang harus dimiliki seorang siswa dalam proses pembelajaran (Odiba dan Baba, 2013; Ayazgok dan Aslan, 2014). Inhelder dan Piaget (Skemp, 1982) mencatat bahwa individu mulai mengembangkan proses berpikir reflektif mulai usia 7 tahun. Pada usia tersebut, seorang anak mampu memanipulasi berbagai ide-ide konkrit dan menceritakan kembali apa yang telah dilakukan (dalam imaginasinya). Penelitian tersebut diperkuat dengan penelitian Gagatsis dan Patronis (1990) yang menemukan bahwa proses berpikir reflektif matematis mulai berkembang pada usia 7-8 tahun dan relatif stabil dalam penentuan strategi penyelesaian masalah terkait dengan model geometri. Lebih lanjut, Gagatsis dan Patronis merekomendasikan untuk mengadakan penelitian terkait proses berpikir reflektif pada siswa dengan usia yang lebih dewasa. Hal ini diperkuat dengan penelitian Moon (1999) yang menyatakan bahwa proses berpikir reflektif antar individu berbeda dan berkembang seiring bertambahnya usia. Gurol (2011) menyatakan bahwa berpikir reflektif dapat dijadikan sebagai sarana untuk mendorong proses berpikir selama pemecahan masalah, karena memberikan kesempatan untuk belajar dan memikirkan strategi terbaik dalam proses pemecahan masalah. Sejalan dengan penelitian tersebut, Kurniawati, dkk (2014) melaporkan bahwa kemampuan berpikir reflektif sangat diperlukan bagi siswa untuk memecahkan masalah, karena dalam kegiatan ini, siswa harus memprediksi jawaban benar dengan segera sehingga dapat mengeksplorasi masalah dengan mengidentifikasi konsep matematika yang terlibat dalam masalah matematika dan menggunakan berbagai strategi. Ketika strategi telah dipilih oleh siswa, mereka perlu membangun ide, menarik kesimpulan, menentukan validitas argumen, memeriksa kembali solusi, dan mengembangkan strategi-strategi alternatif. 
Skemp (1982) melaporkan bahwa proses berpikir reflektif individu terjadi ketika individu merespon lingkungan luar (external environment) diikuti dengan aktivitas mental yang berintervensi (intervening mental activities). Aktivitas mental yang berintervensi tersebut menjadi objek kesadaran untuk instropeksi diri (instropective awareness) yang menghasilkan respon (efectors). Hal ini dipertegas oleh hasil penelitian Kosslyn (2005), bahwa proses berpikir reflektif terjadi ketika informasi yang tersimpan dalam long-term memory (LTM) tidak memungkinkan seseorang untuk merespon secara otomatis ke sebuah objek atau kejadian. Informasi yang tersimpan tersebut harus dimasukkan ke dalam working memory (WM) kemudian respon baru atau solusi dihasilkan. Lebih lanjut, citra mental (mental imagery) memainkan peran penting dalam proses berpikir reflektif. Pemahaman tentang citra mental memberikan informasi terkait dengan adanya gangguan perkembangan kognitif misalnya, kegagalan siswa untuk menggunakan pemikiran reflektifnya dalam kondisi yang tepat bahkan ketika tidak dapat melakukan pemrosesan informasi secara efektif.

Teori pemrosesan informasi memfokuskan perhatian pada bagaimana orang memerhatikan peristiwa-peristiwa lingkungan, mengkodekan informasi-informasi untuk dipelajari, dan menghubungkannya dengan pengetahuan yang ada dalam memori, menyimpan pengetahuan yang baru dalam memori, dan menariknya kembali ketika diperlukan (Schunk, 2012: 228). Dewey (1933) menyatakan bahwa pengetahuan dan pengalaman yang diperoleh individu sebelumnya akan mempengaruhi proses berpikir reflektif. Hal ini dipertegas oleh Sezer (2008) yang menyatakan bahwa untuk mengembangkan proses berpikir reflektif, individu perlu menyadari dan secara aktif mengakses berbagai pengetahuan yang dimiliki sebelumnya. Sementara itu, Ibrahim (2011); Nindiasari (2013) berdasarkan hasil penelitiannya menemukan bahwa salah satu faktor yang perlu diperhatikan dan akan berpengaruh dalam pemerolehan pengetahuan selanjutnya adalah kemampuan matematika yang dimiliki siswa sebelumnya. Galton (Ibrahim, 2011) menekankan bahwa dari sekelompok siswa yang dipilih secara acak, akan selalu dijumpai siswa yang mempunyai kemampuan tinggi, sedang, dan rendah.

Berdasar pada penelitian yang telah dilakukan terkait proses berpikir reflektif maka dilakukan penelitian pendahuluan untuk mengetahui gambaran awal proses berpikir reflektif yang terjadi pada siswa kelas X MAN Ngawi. Penelitian pendahuluan dilakukan dengan memberikan tes pemecahan masalah terkait materi bangun datar dan trigonometri. Tes tersebut diberikan kepada siswa yang berkemampuan awal matematika tinggi dan rendah. Analisis terhadap jawaban dan wawancara mengungkapkan bahwa proses berpikir reflektif siswa yang berkemampuan awal matematika tinggi adalah (1) meyakini bahwa apa yang dibaca dan dipikirkan adalah benar dengan cara membaca soal berulang, 
(2) menyeleksi dan mempertimbangkan kecukupan informasi untuk menyusun rencana pemecahan masalah dengan cara menemukan konsep atau informasi yang terdapat pada pokok dan situasi permasalahan; untuk meyakini rencana awal pemecahan masalah yang disusun adalah benar, dengan cara mengkaitkan antara hasil representasi dengan pokok permasalahan. Pada langkah memilih strategi, menentukan penyelesaian, serta refleksi dan generalisasi, subjek tidak menggunakan proses berpikir reflektifnya. Hal ini dikarenakan ketidakmampuan subjek untuk menentukan strategi penyelesaian yang akan digunakan, sehingga jawaban yang dihasilkan subjek tidak berdasar pada pertimbangan yang cermat. Sedangkan siswa yang berkemampuan awal matematika rendah, dalam menyelesaikan masalah tidak melakukan proses berpikir reflektif dalam setiap tahapan pemecahan masalah. Berdasarkan teori, hasil riset, penelitian pendahuluan, dan mengingat beragamnya kemampuan siswa, sehingga perlu adanya penelitian lanjutan dengan tujuan penelitian yaitu mendeskripsikan proses berpikir reflektif siswa kelas $\mathrm{X}$ MAN Ngawi yang berkemampuan awal matematika tinggi, sedang, dan rendah dalam pemecahan masalah berdasarkan langkah Krulik dan Rudnick.

\section{METODE PENELITIAN}

Penelitian ini dilakukan di MAN Ngawi, pada semester genap tahun ajaran 2014/2015. Subjek penelitian ini adalah siswa kelas X MAN Ngawi tahun ajaran 2014/2015 semester genap yang telah menempuh materi pelajaran trigonometri. Teknik pemilihan subjek penelitian menggunakan purposive sampling yaitu suatu cara pengambilan informan sumber data dengan pertimbangan tertentu. Berdasarkan hasil konsultasi dengan guru matematika didapatkan siswa yang memenuhi kriteria sebagai subjek penelitian sebanyak enam siswa yaitu dua siswa pada masing-masing kategori kemampuan awal matematika. Instrumen utama penelitian adalah peneliti sendiri sebagai pewawancara yang dibantu dengan instrumen bantu berupa soal tes pemecahan masalah dan pedoman wawancara. Validitas data dalam penelitian ini dilakukan dengan triangulasi waktu dan meningkatkan ketekunan.

Data dalam penelitian ini adalah proses berpikir reflektif siswa yang mempunyai kemampuan awal matematika tinggi, sedang, dan rendah dalam pemecahan masalah. Adapun sumber data pada penelitian ini diperoleh dari hasil pekerjaan subjek, wawancara dengan subjek, dan catatan lapangan. Teknik pengumpulan data dalam penelitian ini adalah wawancara berbasis tugas. Adapun teknik analisis data yang dilakukan dalam penelitian ini meliputi: 1) membuat transkrip data verbal dari hasil rekaman (digunakan alat bantu perekam suara); 2) menelaah seluruh data dari sumber yaitu hasil pekerjaan subjek, hasil wawancara, dan catatan lapangan; 3) melakukan reduksi data (reduksi data 
hasil wawancara berbasis tugas, catatan lapangan, dan hasil pekerjaan subjek); 4) menyusun satuan-satuan analisis data dan melakukan pengkodean; 5) menganalisis dan menggambarkan proses berpikir reflektif siswa dalam pemecahan masalah; 6) melakukan penafsiran data; 7) melakukan triangulasi terhadap data pertama dan kedua untuk mendapatkan data yang valid, data yang sudah valid tersebut dikelompokkan berdasarkan kemampuan awal matematika siswa, data yang valid merupakan proses berpikir reflektif siswa dengan kemampuan matematika tinggi, sedang, dan rendah dalam pemecahan masalah matematika; dan 8) menulis laporan hasil penelitian.

\section{HASIL PENELITIAN DAN PEMBAHASAN}

Data penelitian yang dikumpulkan adalah proses berpikir reflektif siswa yang diperoleh dari wawancara berbasis tugas pemecahan masalah. Tugas berupa tes pemecahan masalah yang terkait dengan materi bangun datar dan trigonometri yang diberikan kepada subjek, hasil pekerjaan subjek dijadikan sebagai dasar wawancara berbasis tugas, kemudian dianalisis sehingga diperoleh kesimpulan sementara proses berpikir reflektif subjek. Pada waktu yang berbeda, subjek diberikan tes pemecahan masalah yang isomorfik dengan tes pemecahan masalah sebelumnya yang dilanjutkan dengan wawancara berbasis tugas, data kemudian dianalisis dan dilakukan triangulasi untuk mengetahui keajegan data. Analisis dilakukan dengan mengelompokkan data sesuai dengan langkah-langkah pemecahan masalah Krulik dan Rudnick.

Hasil penelitian ini adalah sebagai berikut.

Proses berpikir reflektif siswa kelas $X$ MAN Ngawi yang berkemampuan awal matematika tinggi dalam pemecahan masalah berdasarkan langkah Krulik dan Rudnick.

Pada langkah membaca dan berpikir, siswa meyakini apa yang dibaca dan dipikirkan benar dengan membaca soal secara berulang, memberikan makna setiap kalimat soal pemecahan masalah, dan merepresentasikan masalah.

Pada langkah mengeksplorasi dan merencanakan, siswa menyeleksi dan mempertimbangkan berbagai informasi untuk menyusun rencana pemecahan masalah adalah dengan (a) menganalisis konsep atau informasi yang ada pada pokok permasalahan dan situasi masalah; (b) menghasilkan dan memeriksa kembali kebenaran informasi yang akan digunakan; dan (c) menggunakan instuisi dan bertanya pada diri sendiri (self-questioning) untuk meyakini bahwa informasi tersebut dapat digunakan untuk menyusun rencana penyelesaian masalah. Siswa meyakini rencana awal pemecahan masalah yang disusun benar dengan cara (a) mengorganisasikan masalah; (b) memutuskan dengan tegas berbagai rencana awal yang disusun; dan (c) menggunakan 
intuisi dan bertanya pada diri sendiri untuk yakin bahwa rencana yang disusun adalah benar. Solso (2008: 297) mengistilahkan representasi pengetahuan secara visual sebagai perumpamaan atau pembayangan mental (mental imagery). Kaldrimidou (Gagatsis dan Patronis, 1990) mencatat bahwa pembayangan mental sebagai objek mental untuk melakukan proses berpikir reflektif. Selain itu, pembayangan mental akan membantu individu untuk menyelesaikan masalah. Lebih lanjut, pembayangan mental akan membantu individu untuk mereorganisasikan berbagai pengetahuan dan merekonstruksi konsep dari masalah. Clark dan Paivio (Solso, 2008: 311) menyatakan bahwa LTM memiliki dua sarana untuk merepresentasikan pengetahuan yaitu sistem verbal dan sistem imaginal. Sistem verbal memasukkan pengetahuan yang diekspresikan dengan bahasa sedangkan sistem imaginal atau sistem gambar menyimpan informasi visual dan spasial. Kedua sistem ini saling berkaitan, sebuah kode verbal dapat dikonversi menjadi sebuah kode imaginal atau kode gambar, demikian sebaliknya. Berbeda dengan teori dua-kode, teori unier (unitary teory) yang menyatakan bahwa semua informasi direpresentasikan dalam LTM dalam bentuk kode-kode verbal (proposisi-proposisi).

Pada langkah menentukan strategi, siswa mempertimbangkan bahwa strategi pemecahan masalah yang ditentukan berdasar pada data dan informasi yang diperoleh dengan (a) mengembangkan rencana awal penyelesaian dengan bekerja pada hasil representasi secara trial-error dan guess-test; (b) menentukan pola pemecahan masalah; dan (c) memeriksa kembali setiap proses yang dilakukan; dan (c) menggunakan intuisi dan bertanya pada diri sendiri untuk meyakini strategi pemecahan masalah yang dipilih adalah benar. Feldman (2012: 314) menyatakan bahwa untuk menemukan solusi dapat dilakukan dengan menggunakan strategi trial-error. Penyelesaian masalah yang kompleks seringkali melibatkan penggunaan heuristik, jalur pendek kognitif yang dapat menghasilkan solusi. Heuristik yang paling sering digunakan dalam pemecahan masalah adalah analisis mens-end. Suatu analisis mens-end setiap langkah membawa individu semakin dekat dengan suatu resolusi. Meskipun pendekatan ini sering kali efektif jika masalah tersebut memerlukan langkah tidak langsung yang secara temporer meningkatkan diskrepansi antara suatu kondisi saat ini dengan solusi, analisis mens-end menjadi tidak produktif.

Pada langkah menentukan penyelesaian, siswa memahami setiap langkah pengerjaan berdasar strategi pemecahan masalah yang dipilih dengan (a) memastikan rumus yang digunakan (luas bangun datar, luas segitiga jika diketahui dua buah sisi yang mengapit sebuah sudut, dan perbandingan trigonometri untuk sudut istimewa berdasarkan pertimbangan yang kuat dan cermat); (b) mengerjakan berulang dengan menggunakan pola yang dipilih; (c) memeriksa dan mencermati setiap langkah pengerjaan dan 
perhitungan yang dilakukan dengan bekerja mundur; (d) menyadari adanya kesalahan (rumus, komputasi, dan nulis) dan memperbaikinya; dan (e) menggunakan intuisi dan bertanya pada diri sendiri untuk meyakini langkah-langkah pengerjaannya sesuai dengan cara yang dipilih.

Pada langkah refleksi dan generalisasi, siswa mempertimbangkan kesesuaian antara hasil yang diperoleh dengan masalah yang ada dengan dengan (a) merefleksi setiap proses yang dilakukan untuk mendapatkan solusi; dan (b) menguji kebenaran kesimpulan yang diambil dengan memverifikasi informasi; dan (c) menggunakan intuisi dan bertanya pada diri sendiri untuk meyakini bahwa solusi yang diperoleh sudah menjawab permasalahan yang ada.

Satu hal yang menarik yang ditunjukkan oleh subjek dengan kemampuan awal matematika tinggi adalah setiap langkah pemecahan masalah yang dilaluinya dengan cara bertanya pada diri sendiri (self-questioning). Hasil penelitian ini semakin menguatkan penelitian terdahulu yang dilakukan oleh Teekman (2000). Teekman mencatat dari hasil studinya bahwa bertanya pada diri sendiri merupakan hal yang penting dalam menunjang pengembangan proses berpikir reflektif. Lebih lanjut, bertanya pada diri sendiri digunakan untuk mengkreasikan dan memahami makna suatu objek mental. Lebih lanjut, beberapa manfaat bertanya pada diri sendiri adalah 1) membantu individu untuk mengklarifikasi dan mengkategorikan situasi dan kejadian, dan berkontribusi untuk keterampilan logika berpikir; 2) membantu untuk menstrukturisasi proses berpikir dan mengurangi kemungkinan overlooking aspek penting dalam suatu kejadian; 3) membantu individu untuk membuat makna dari suatu situasi dan merencanakan apa yang harus dilakukan selanjutnya; dan 4) membantu individu untuk mengklarifikasi skema atau aturan yang ada dalam diri yang kemudian digunakan untuk merespon dalam konteks yang lebih luas.

Hal lain yang dilakukan siswa dengan kemampuan awal matematika tinggi yaitu menggunakan instuisinya untuk meyakinkan dirinya sendiri apa yang telah dilakukannya adalah benar. Intuisi dijelaskan oleh Fischbein (1999) sebagai kognisi yang secara subjektif kebenarannya terkandung di dalamnya, dapat diterima dengan sendirinya dan langsung, holistik, penggiringan dan pemerkiraan. Salah satu karakteristik intuisi Fischbein (1999) adalah coerciveness, yaitu intuisi mempunyai sifat menggiring kearah sesuatu yang diyakini. Hal ini berarti bahwa individu cenderung menolak interpretasi alternatif yang akan kontradiksi dengan intuisinya. Hal ini sejalan dengan penelitian Hogarth (2001) yang menyatakan bahwa intuisi akan hadir dan digunakan ketika berhadapan dengan dilema pemecahan masalah atau pengambilan keputusan. Proses yang mendasari intuisi pemecahan masalah adalah mencocokkan pola yang dapat 
dipertajam melalui pelatihan dan latihan berulang. Senada dengan hal tersebut, Fischbein (1999) menyatakan bahwa intuisi dapat dijadikan sebagai mediating cognitive yang dapat dijadikan jembatan pemahaman seseorang, sehingga dapat membantu dan memudahkan dalam mengaitkan objek yang dibayangkan dengan alternatif solusi yang diinginkan.

Proses berpikir reflektif siswa kelas $X$ MAN Ngawi yang berkemampuan awal matematika sedang dalam pemecahan masalah berdasarkan langkah Krulik dan Rudnick.

Pada langkah membaca dan berpikir, siswa meyakini yang dibaca dan dipikirkan benar dengan membaca soal secara berulang dan merepresentasikan masalah.

Pada langkah mengeksplorasi dan merencanakan, siswa menyeleksi dan mempertimbangkan berbagai informasi untuk menyusun rencana pemecahan masalah dengan menganalisis konsep atau informasi yang ada pada pokok permasalahan dan situasi masalah. Siswa meyakini rencana awal yang disusun adalah benar dengan mengorganisasikan masalah dan memutuskan berbagai rencana awal yang disusun.

Pada langkah memilih strategi, siswa mempertimbangkan rencana/strategi pemecahan masalah yang ditentukan berdasar pada data dan informasi yang diperoleh dengan (a) mengembangkan rencana awal penyelesaian dengan bekerja pada hasil representasi secara trial and error; (b) membuat keputusan pola pemecahan masalah yang dipilih secara tepat, namun dengan stimulus pertanyaan.

Pada langkah menentukan penyelesaian, siswa memahami setiap langkah pengerjaan berdasar pada strategi pemecahan masalah yang dipilih adalah benar dengan cara (a) memastikan rumus yang digunakan terkait luas bangun datar, luas segitiga jika diketahui dua buah sisi yang mengapit sebuah sudut, dan perbandingan trigonometri untuk sudut istimewa dengan tepat, namun harus dibantu stimulus pertanyaan; (b) mengerjakan berulang dengan menggunakan pola yang dipilih dan memeriksa setiap langkah pengerjaan dan perhitungan yang dilakukan; dan (c) menyadari adanya kesalahan (strategi penyelesaian, rumus, komputasi, dan nulis) dan memperbaikinya dengan stimulus pertanyaan. Fenomena yang menarik adalah siswa mengerjakan dengan dua cara yang menghasilkan jawaban yang berbeda. Terkait dengan fenomena tersebut, Feldman (2012: 315) menjelaskan bahwa fenomena tersebut terjadi karena adanya kesadaran tibatiba (insight). Beberapa pendekatan untuk menciptakan kemungkinan solusi kurang berfokus pada heuristik langkah demi langkah dibandingkan terhadap ledakan pemahaman tiba-tiba yang mungkin dialami seseorang pada saat mereka berusaha untuk menyelesaikan suatu masalah. Fenomena tersebut terjadi akibat evaluasi yang tidak 
akurat terhadap solusi, yang selanjutnya dikenal sebagai bias konfirmasi. Bias konfirmasi merupakan tendensi untuk mencari dan lebih condong kepada informasi yang mendukung hipotesis awal seseorang dan untuk menghindari informasi berlawanan yang mendukung hipotesis alternatif atau solusi. Bias konfirmasi ini terjadi karena memikirkan kembali suatu masalah yang sepertinya telah teratasi, individu cenderung bertahan dengan solusi pertama. Pada langkah merefleksi dan generalisasi, siswa mempertimbangkan kesesuaian antara hasil yang diperoleh dengan permasalahan yang ada dengan memeriksa dan memastikan benar pokok permasalahan yang ada dan solusi yang diperoleh.

\section{Proses berpikir reflektif siswa kelas $X$ MAN Ngawi yang berkemampuan awal matematika rendah dalam pemecahan masalah berdasarkan langkah Krulik dan Rudnick.}

Siswa kelas X MAN Ngawi yang berkemampuan awal matematika rendah tidak melakukan proses berpikir reflektifnya dalam pemecahan masalah berdasarkan langkah Krulik dan Rudnick. Akan tetapi, terdapat dua hal yang menjadi catatan, siswa pada kategori ini seringkali mengucapkan kata lupa dan menyadari adanya kesalahan akan tetapi tidak mengetahui bagaimana cara memperbaikinya. Lupa merujuk pada porsi pengetahuan atau kemampuan yang hilang dalam memori. Gejala lupa mudah terjadi pada pengetahuan kognitif bila individu tidak berhasil mengkonstruksi pengetahuannya sendiri atau mengaitkan pengetahuan atau konsep yang telah dipelajarinya dengan pengetahuan atau konsep yang telah dimilikinya Winkel (2004, 446-452). Lebih lanjut, salah satu sebab terjadinya lupa adalah para siswa tidak mendapat kunci yang tepat untuk membuka ingatannya, sehingga kesukarannya timbul pada fase penggalian itu sendiri. Gejala lupa disebabkan kurang perhatian pada fase konsentrasi dan pengolahan materi yang tidak sempurna (fiksasi) sebelum dimasukkan dalam long-term memory (LTM). Sebagian materi yang seharusnya diolah, hanya disentuh sebentar dan kemudian keluar, sebagian dari materi diolah dalam sort-term memory (STM) secara tidak sempurna dan kemudian dimasukkan ke long-term memory (LTM) dalam keadaan setengah matang. Akibatnya tidak terdapat organisasi yang baik dalam long-term memory (LTM). Sementara itu, para psikolog menyatakan empat hal yang menyebabkan lupa yaitu kegagalan untuk memanggil kembali (failure to retrieve), kesalahan rekonstruksi (reconstruction error), interferensi (interference), dan kerusakan (decay) (Ormrod, 2008). Hasil wawancara menunjukkan bahwa subjek menyadari adanya kesalahan, akan tetapi tidak mampu untuk memperbaiki kesalahan tersebut. Terkait dengan fenomena ini, Skemp (1982: 54-55) menggambarkannya sebagaimana bagan sebagai berikut. 


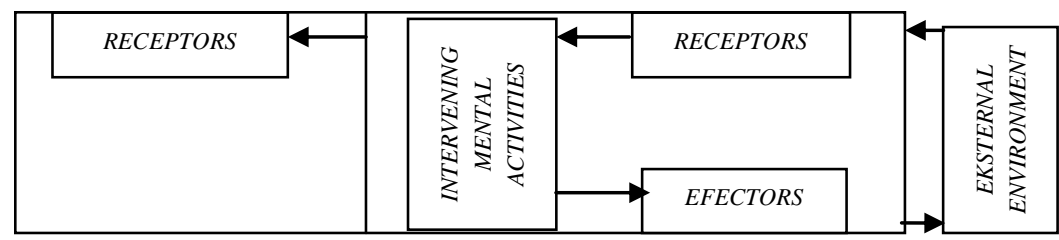

Bagan Terjadinya Proses Berpikir Reflektif

Berdasarkan bagan tersebut, Skemp (1982; 54-55) menjelaskan fenomena siswa menyadari adanya kesalahan terjadi karena pada aktivitas mental (intervening mental activities) terjadi kesadaran untuk introspeksi (introspective awareness). Akan tetapi, individu tidak mampu untuk menemukan solusi dari introspeksi tersebut.

\section{SIMPULAN DAN SARAN}

Berdasarkan hasil penelitian dan pembahasan, diperoleh kesimpulan sebagai berikut. Proses berpikir reflektif siswa kelas X MAN Ngawi yang berkemampuan awal matematika tinggi dalam pemecahan masalah berdasar langkah Krulik dan Rudnick yaitu: (1) pada langkah membaca dan berpikir, siswa meyakini apa yang dibaca dan dipikirkan benar dengan (a) membaca soal berulang; (b) memberikan makna setiap kalimat tes pemecahan masalah, dan (c) merepresentasikan masalah; (2) pada langkah mengeksplorasi dan merencanakan, siswa menyeleksi dan mempertimbangkan berbagai informasi untuk menyusun rencana awal pemecahan masalah dengan (a) menganalisis konsep atau informasi yang ada pada pokok permasalahan dan situasi masalah; dan (b) menghasilkan dan memeriksa kembali kebenaran informasi yang akan digunakan. Siswa meyakini rencana awal pemecahan masalah yang disusun adalah benar dengan cara (a) mengorganisasikan masalah; (b) memutuskan dengan tegas berbagai rencana awal yang disusun; (3) pada langkah memilih strategi, siswa mempertimbangkan strategi pemecahan masalah yang ditentukan berdasar pada data dan informasi yang diperoleh dengan (a) mengembangkan rencana awal penyelesaian dengan bekerja pada hasil representasi secara trial-error dan guess-test; (b) menentukan pola pemecahan masalah; dan (c) memeriksa kembali setiap proses yang dilakukan; (4) pada langkah menentukan penyelesaian, siswa memahami setiap langkah pengerjaan berdasar pada strategi pemecahan masalah yang dipilih adalah benar dengan (a) memastikan rumus yang digunakan (luas bangun datar, luas segitiga jika diketahui dua buah sisi yang mengapit sebuah sudut, dan perbandingan trigonometri untuk sudut istimewa berdasarkan pertimbangan yang kuat dan cermat); (b) mengerjakan berulang dengan menggunakan pola yang dipilih; (c) memeriksa dan mencermati setiap langkah pengerjaan dan perhitungan yang dilakukan dengan bekerja mundur; dan (d) menyadari adanya kesalahan (rumus, komputasi, dan nulis) dan memperbaikinya; (5) pada langkah merefleksi dan generalisasi, siswa mempertimbangkan kesesuaian antara hasil yang diperoleh dengan 
permasalahan yang ada dengan (a) merefleksi setiap proses yang dilakukan untuk mendapatkan solusi; dan (b) menguji kebenaran kesimpulan yang diambil dengan memverifikasi informasi. Pada setiap langkah pemecahan masalah selalu menggunakan intuisi dan bertanya pada diri sendiri (self questioning) untuk meyakinkan diri apa yang dilakukan adalah benar.

Proses berpikir reflektif siswa kelas X MAN Ngawi yang berkemampuan awal matematika sedang dalam pemecahan masalah berdasar langkah Krulik dan Rudnick yaitu (1) pada langkah membaca dan berpikir, siswa meyakini apa yang dibaca dan dipikirkan benar dengan membaca soal berulang dan merepresentasikan masalah. (2) pada langkah mengeksplorasi dan merencanakan, siswa menyeleksi dan mempertimbangkan berbagai informasi untuk menyusun rencana pemecahan masalah dengan menganalisis konsep atau informasi yang ada pada pokok permasalahan dan situasi masalah. Siswa meyakini rencana awal yang disusun benar dengan cara mengorganisasikan masalah dan memutuskan berbagai rencana awal yang disusun; (3) pada langkah memilih strategi, subjek mempertimbangkan strategi pemecahan masalah yang ditentukan berdasar pada data dan informasi yang diperoleh dengan (a) mengembangkan rencana awal penyelesaian dengan bekerja pada hasil representasi secara trial and error; (b) membuat keputusan pola pemecahan masalah yang dipilih secara tepat, namun dengan stimulus pertanyaan; (4) pada langkah menentukan penyelesaian, siswa memahami setiap langkah pengerjaan berdasar pada strategi pemecahan masalah yang dipilih adalah benar dengan (a) memastikan rumus yang digunakan terkait luas bangun datar, luas segitiga jika diketahui dua buah sisi yang mengapit sebuah sudut, dan perbandingan trigonometri untuk sudut istimewa dengan tepat, namun harus dibantu stimulus pertanyaan; (b) mengerjakan berulang dengan menggunakan pola yang dipilih dan memeriksa setiap langkah pengerjaan dan perhitungan yang dilakukan; dan (c) menyadari adanya kesalahan (strategi penyelesaian, rumus, komputasi, dan nulis) dan memperbaikinya dengan stimulus pertanyaan; (5) pada langkah merefleksi dan generalisasi, siswa mempertimbangkan kesesuaian antara hasil yang diperoleh dengan permasalahan yang ada dengan cara memeriksa dan memastikan benar pokok permasalahan yang ada dan solusi yang diperoleh.

Proses berpikir reflektif siswa kelas X MAN Ngawi yang berkemampuan awal matematika rendah dalam pemecahan masalah berdasar langkah Krulik dan Rudnick yaitu siswa tidak menggunakan proses berpikir reflektifnya selama pemecahan masalah.

Berdasarkan temuan penelitian ini dapat dikemukakan saran sebagai berikut. (a) Guru ka sebaiknya memperhatikan perbedaan kemampuan awal matematika siswa, yaitu: (1) untuk siswa berkemampuan awal matematika tinggi,sebaiknya diberikan soal-soal 
pemecahan masalah yang lebih bervariasi sehingga siswa akan lebih terbiasa untuk berpikir reflektif; (2) siswa dengan kemampuan awal matematika sedang masih kebingungan dalam menentukan solusi dan memunculkan dua cara penyelesaian dengan hasil yang berbeda, guru hendaknya lebih sering membimbing siswa dengan memberikan soal-soal pemecahan masalah yang mampu mengembangkan kemampuan awal matematika yang telah dimiliki siswa sebelumnya; dan 3) siswa dengan kemampuan awal matematika rendah tidak melakukan proses berpikir reflektif pada setiap langkah pemecahan masalah, guru hendaknya lebih rutin dalam membimbing siswa yang disesuaikan dengan tahap perkembangan pengetahuan siswa dan memilih model pembelajaran yang tepat. (b) Bagi peneliti yang ingin melakukan penelitian sejenis terkait dengan proses berpikir reflektif siswa dalam pemecahan masalah agar dapat mengembangkan penelitian ini, yaitu meneliti pada subjek yang lebih luas dan memilih materi yang berbeda.

\section{DAFTAR PUSTAKA}

Ayazgok, B. dan Aslan, H. 2014. The Review of Academic Perception, Level of Metacognitive Awareness and Reflective Thinking Skills of Science and Mathematics University Student. Procedia - Social and Behavioral Sciences 141, PP. $781-790$.

Dewey, J. 1933. How We Think: A Restatement of the Relation of Reflective Thinking to the Educative Process. Boston, MA: D.C., Heath and Company. [Online]. Tersedia: rci.rutgers.edu_tripmcc_phil_dewey-hwt-pt1-selections.pdf

Feldman, R. S. 2012. Understanding Psychology $10^{\text {th }}$ ed. New York: McGraw-Hill.

Fischbein, E. 1999. Intuitions and Schemata in Mathematical Reasoning. Educational Studies in Mathematics, Vol. 38., PP-27-47.

Gagatsis, A. dan Patronis, T. 1990. Using Geometrical Models in a Process of Reflective Thinking in Learning and Teaching Mathematics. Educational Studies in Mathematics Netherlands, Vol. 21, PP. 29-54.

Gurol. A. 2011. Determining the Reflective Thinking Skills of Pre-Service Teachers in Learning and Teaching Process. Energy Education Science and Technology Part B: Social and Educational Studies, Vol. (Issue) 3(3), PP. 387-402.

Hogarth, R. 2001. Educating Intuition. Chicago: University of Chicago Press.

Ibrahim. 2011. Peningkatan Kemampuan Komunikasi, Penalaran, dan Pemecahan Masalah Matematis serta Kecerdasan Emosional Melalui Pembelajaran Berbasis Masalah Pada Siswa Sekolah Menengah Atas. Disertasi pada SPS UPI. Bandung: Tidak Diterbitkan.

Kosslyn, S. M. 2005. Reflective Thinking and Mental Imagery: A Perspective on the Development of Posttraumatic Stress Disorder. Development and Psychopathology Journal, Vol.17, PP. 851-863, Cambridge University Press. 
Krulik, S. dan Rudnick, J. A. 1988. Problem Solving: A Handbook for Teachers. Boston: Allyn\& Bacon.

Kurniawati, L., Kusumah, Y. S., Sumarmo, U., dan Sabandar, J. 2014. Enhancing Students' Mathematical Intuitive-Reflective Thinking Ability Through ProblemBased Learning with Hypoteaching Method. Journal of Education and Practice, Vol.5, No.36.

McIntosh, R. 2000. Teaching Mathematical Problem Solving: Implementing The Visions. [Online]. Tersedia: http://www.nwrel.org/msec/images/mpm/pdf/ monograph.pdf. [2 Mei 2014].

Moon, J. 1999. Reflection in Learning \& Professional Development: Theory and Practice. London: Kogan Page. [Online]. Tersedia: https://books.google.co.id/books?hl=en\&lr=\&id=8y0LwQxZUf4C\&oi=fnd \&p $\mathrm{g}=\mathrm{PR} 2 \& \mathrm{dq}=$ Reflection+in+Learning+\%26+Professional+Development:+Theo ry+and+Practice\&ots=1rZDrtSSfS\&sig=d7i4PQ9fQoE1gFtblf89oUnSoJE\&re dir_esc=y\#v=onepage \&q=Reflection $\% 20$ in $\% 20$ Learning $\% 20 \% 26 \% 20$ Profess ional\%20Development\%3A\%20Theory\%20and\%20Practice $\& \mathrm{f}=$ false. [3 Mei 2014].

National Council of Teachers of Mathematics (NCTM). 2015. Classroom Resources. [Online]. Tersedia: http://www.nctm.org/Conferences-and-ProfessionalDevelopment/Research-Conference/. [5 Februari 2015]

Nindiasari, H. 2013. Meningkatkan Kemampuan dan Disposisi berpikir Reflektif Matematis serta Kemampuan Belajar Siswa SMA melalui Pembelajaran dengan Pendekatan Metakognitif. Disertasi PPS UPI. Bandung: Tidak diterbitkan.

Odiba, I. A. dan Baba, P. A. 2013. Using Reflective Thinking Skills for Education Quality Improvement in Nigeria. Journal of Education and Practice, Vol.4, No.16.

Ormrod, E.J. 2008. Psikologi Pendidikan. Jakarta: Erlangga.

Schunk, D. H. 2012. Learning Theories an Educational Perspective, Sixthh Edition. Penerjemah: Eva Hamdiah dan Rahmat Fajar. Yogyakarta: Pustaka Pelajar.

Sezer, R. 2008. Integration of Critical Thinking Skills into Elementary School Teacher Education Courses in Mathematics. Education, Vol (Issue)128(3), PP. 349-362.

Skemp, R. R. 1982. The Psychology of Learning Mathematics. Great Britain: Penguin Books.

Solso, L.R., Maclin, H.O., dan Maclin, K. M. 2008. Psikologi Kognitif. Jakarta: Erlangga.

Winkel, W.S. 1996. Psikologi Pengajaran. Jakarta: Gramedia 